\title{
Acting in a Globalized World: Marketing Perspective
}

\author{
Gabriel Awuah
}

Additional information is available at the end of the chapter

http://dx.doi.org/10.5772/45658

\section{Introduction}

There is the notion that the world has become a global village, implying that the increased exchange relationships among a multitude of actors (nations, institutions, organizations/firms, and private individuals) have resulted in interdependence among many actors (Wei and Lau, 2008; Peng, Wang, and Jiang, 2008; Lee, 2005; Curry, 2000). As Lee (2005) expresses it, our tastes, needs, wants and demands are converging, a trend which is termed as "global consumers". An important implication of the increased exchanges among several actors in our globalized world is the increased interdependencies at all levels of human interactions (e.g. national, organization/firm, and private levels). Evidently, nations, for example, that are interdependent have increasingly opened their economies to facilitate the technological, political, and cultural exchanges among them (Human Development Report, 2004; Curry, 2000). As reported in the Human Development Report (2004, p. 85), contacts between people and their values, ideas, and ways of life have all increased in an unprecedented way.

Technological, economic, political, and socio-cultural exchanges among several actors in our globalized world (Peters and Pierre, 2006; Lee, 2005; Human Report development, 2004) have numerous benefits and at the same time challenges, which need be understood and managed (Li, Qiu, and Wan, 2011). It has become an established fact that researchers agree on the dual effects of globalization; globalization provides global market opportunities and global market challenges (p. 1016). Of importance, then, is to discuss some effects of interdependencies among actors acting in the globalized world. Prior to discuss the effects of interdependencies, we state the purpose for the chapter.

Globalization and liberalization of markets will leave no firm, anywhere, in any market, free from intense competition from foreign and domestic markets. But, not all firms will be able to exploit opportunities and handle challenges, which globalization brings with it. The 
purpose of the chapter, therefore, is to review and discuss some of the opportunities and challenges, which are inherent in our globalized markets and suggest some ways regarding how a firm can create and sustain its competitiveness over time.

\section{Some effects of interdependencies}

\section{Benefits of globalization}

Acting in the globalized world all actors (nations, institutions, organizations/firms, and private individuals) appear to benefit from the increased liberalization of markets, more especially socio-economic reforms, which is considered as the necessary condition for the realization of the full impact of globalization (Li, et al., 2011; Wei and Lau, 2008; Peters and Pierre, 2006). Private individuals have access to not only great many things, but also varieties and choices. Foreign goods and services are in abundance, for example, in almost any town, city or village in Africa, south of Sahara. These goods and services range from agriculturally processed goods (e.g. tin tomatoes and canned meat from Europe and South America) to sophisticated high-tech goods (e.g. computers, medical equipment, electronic equipment, mobile phones, cable T.V. sets, and automobiles) plus basic industrial raw materials and components such as iron and steel, motor spare parts and machines and machine tools from Europe, North America, and Asia (Awuah, 2009; Spiegel, 2007).

On the firm level, the substitute of a larger global market for the firm's limited domestic market will be a great benefit of globalization. There were periods when most markets were heavily regulated and/or controlled; hence, exporting goods or services into other markets was restricted (Teece, 1985; Unger, 1989; Todaro, 1994). As Czinkota and Ronkainen posit (2007, p. 189), many firms, especially "Mininationals" or "Born Globals" do benefit from increased trade liberalization in that they are able to serve many markets from a handful of manufacturing bases. Thus, in the era of increased globalization and/or trade liberalization, many firms are not compeled to build a plant in every country as some established multinational corporations once had to do (Doole and Lowe, 2008; Czinkota and Ronkainen, 2007). Moreover, globalization is seen to expand firms' market potential, increase their resources accessibility, promote their output growth, and also help them to procure foreign outsourcing ( $\mathrm{Li}$, et al., 2011). For example, forging co-operative exchange relationships with other firms in order to get access to foreign firms' resources and activities, through outsourcing relationships, will lead to complementary exchange relationships among the interacting actors. Through the complementary exchange relationships among interdependent actors, almost all countries, organizations/firms, and private individuals have a greater access to products, services, technologies and practices, which may be modern, effective, and superior to some existing ones (Wei and Lau, 2008).

On the global and national levels, as argued by Lee (2005), the global integration has some positive effects. For Lee, the interdependence among nations, effects of globalization, has enabled the entire world's productivity to grow rapidly. As reported elsewhere, (Czinkota and Ronkainen 2007, p. 5) there was an expansion of world trade during 2000 to 2005. In 
merchandise, the increase was from $\$ 6.2$ trillion to over $\$ 9$ trillion. In services, the increase was from $\$ 1.5$ trillion to $\$ 2.1$ trillion. Taken together, the worldwide growth of goods and services was $150 \%$ (p. 5). On the national level, the following country growths are worth reporting. China's economic growth rate since, 1990s has been on the average $10 \%$, the highest in the world. In 2009, however, the growth rate decreased a little bit, $8.7 \%$; this was the time when other global economies were in deep recession (Chuang, M-L., et al, 2011). A Swedish trade figure shows the extent to which a small country such as Sweden can benefit from increased world trade. As reported elsewhere (www.economywatch.com), in January 2010, Sweden's exports amounted to 78.4 billion Kronor, while its imports were 70.9 billion kronor.

"While globalization has led to substantial economic growth overall, the benefits of globalization have not been shared equally among states" (Carasco and Singh, 2009, p. 259).

It is beyond the scope of this chapter to exploit the controversy around the benefits and disadvantages of globalization (for some readings on this see, e.g. Awuah and Amal, 2011; Awuah, 2009; Carasco and Singh, 2009; Peters and Pierre, 2006; Human Development Report, 2004). At any rate, some challenges emanating from the increased interdependence among many actors in our globalized world are discussed below.

\section{Some challenges of globalization}

\section{Handling socio-cultural, technological, economic and institutional barriers}

Interacting actors, especially countries and business firms will have an increased exposure to challenges emanating from economic and institutional barriers. The Japanese currency market as well as the Chinese currency market is considered to be manipulated in that they are intentionally said to be held low in relation to other major trade currencies such as those of the U.S dollar and the Euro. This is a development, when not remedied, would render goods and services exported from the U.S and Europe into Japan or China to be expensive. This is because a Japanese customer will have to have more money in order to buy a comparative good/service (from the U.S or Europe that are being sold in Japan). The same will apply to the relative expensive comparative good/service (from the US and Europe, but being sold in China). The challenge is that it is not the physical evidence that U.S or European goods/services are expensive in Japan or China, but it is difficult to prove that there is a conscious economic or institutional barrier on the part of the Japanese or Chinese public policy instrument to devalue their currencies. The Japanese and Chinese authorities have constantly denied such accusation of currency manipulation, which the West put on them. Japan is also said to have imposed one of the highest farm tariffs in the industrialized markets (Financial Times: November 10, 2011:4). It is also reported elsewhere (Peng, M.W., et al., 2008; Spiegel Special, 2007; Beamish and Lu, 2004) that almost all industrial countries still have some trade barriers or subsidies, which protect their domestic companies from competition from abroad. 
As Wal-Mart and Carrefour have been experiencing in China, offering retail services in an environment, where the socio-cultural forces constrain their design and implementation of strategies, have resulted in each of the firms having difficulty to implement standardization strategies, which have enabled them maintain leadership position in, for example, Canada and Mexico (in the case of Wal-Mart) and in Europe (in the case of Carrefour). For the Chinese market, the firms in question are said to be struggling for leadership; but, for that to be achieved, they will need to overcome socio-cultural barriers (Chuang, M-L, et al., 2011).

\section{Increased competition and domestic job opportunities}

Concern has been raised about, for example, the harm that global sourcing can do to local and national economy (Cavusgil, Knight, and Riesenberger, 2012), namely, job losses in the home country, reduced national competitiveness, and declining standard of living.

"A major concern is job losses. The number of jobs in the U.S. legal industry outsourced to foreign contractors now exceeds 25,000 per year. Some estimate that more than 400,000 jobs in the United States IT industry have moved offshore" (p. 507).

Walmart, the world's largest retail chain is said to source as much as $70 \%$ of its finished merchandise from abroad, a strategy which has made some concerned citizens in the U.S to form a protest group called Walmartwatch.com against the giant world retail chain (p. 508). As the authors maintain, job losses are occurring in developing economies as well. For instance, in the textile industry, El Salvador, Honduras, Indonesia, and Turkey have seen jobs gradually being transferred to China, India, and Pakistan (p. 508).

\section{Increased vulnerability: Interdependencies demand collective action}

There is no denying the fact that nations, organizations/firms, and even private individuals over the globe will all be vulnerable to some crises and/or security issues, which occur and negatively impact our increased socio-cultural, technological, economic and political exchanges. The global financial meltdown of 2007-2009, which was triggered by the bursting of the U.S. housing price bubble and the resulting increase in mortgage delinquencies, brought financial crises to many countries (see e.g. Allen, Chakraborty, and Watanbe, 2011). The current Eurozone Debt Crisis, where some countries within the Eurozone are on the brink of financial collapse, when not properly handled by all the interdependent world trade partners, will bring a greater economic recession, which will affect world trade in total. Finally, we are all vulnerable; therefore, our interdependent exchange relationships will not leave many actors spared from, example, the spread of pandemics (e.g. the E.Coli outbreak, which took some lives in Germany and in some Western countries). The Herald Tribune added a note to underlie this interdependency when the E.Coli outbreak, some food poisoning traced to the eating of tomatoes and cucumbers, occurred this year, 2011; "the supply chains for tomatoes and cucumbers can be difficult to untangle" (Herald Tribune, June 4-5, 2011:4). 
The above examples of challenges cannot be handled by any single actor in any economy. It behoves several actors, having heterogeneous resources and performing varied activities, in our globalized world, to establish exchange relationships, which will enable them to handle challenges, which are of concern to all. An in-depth discussion of the effects of globalization will be taken up, later on in this chapter, on the firm level, where we discuss in some detail why and how firms need to create and sustain their competitiveness as they act in our globalized world.

\section{Competitiveness of firms in the globalized world}

From the preceding sections, it can be deduced that, due to globalization, the distinction between national markets, for some products and services, are fading away (Czinkota and Ronkainen, 2007). Substituting the global market for the smaller domestic market becomes imperative for most firms, especially those operating in global industries such as the electronic, automobile, telecommunication, and appliances industries. With increased globalization and increased liberalization of national markets (e.g. less barriers to trade), any firm should strive to exploit the numerous opportunities inherent in globalization. Thus, there is a tremendous increased homogeneity in our needs and tastes, access to large markets, modern and superior technologies, superior goods/services, and falling costs of doing business across the globe (Cavusgil, et al., 2012; Carasco and Singh, 2009; Lee, 2005; Knight and Cavusgil, 1996).

However, globalization is not without its challenges. For example, some markets, and the firms operating in them, will not be capable to quickly respond to the rapid transformation processes of globalization and trade liberalization (Awuah and Amal, 2011). Most firms will not have the capabilities to deal with increased competition, which increased globalization and trade liberalization bring with them. But, as argued earlier on, globalization and trade liberalization will leave no firm, in any market, free from intense competition in foreign and domestic markets. As Doyle and Stern (2006) posit, success for most companies is a temporal phenomenon; things change rapidly, consumers needs and wants change rapidly in response to market dynamism, and competitors get better. As reported elsewhere (StiGlitz, 2006) General Motor's (GM's), an automobile giant, revenue in 2004 was \$191, 4 billion, more than the BNP of 148 countries. But, in 2008, GM nearly went bankrupt and had to be bailed out by the U.S. government.

If a firm is not able to create sustainable value for its customers, as Doyle and Stern (2006) contend, the competitive advantage of the firm will be a temporal success as GM's example portrays. A firm needs to create value for its customers, which the firm's competitors cannot match over time, a performance that will ensure a sustainable competitive advantage. The notion of creating value for a firm's customers is supported in the literature. For Porter (1985), a firm's competitive advantage grows fundamentally out of the value the firm can create for its customers.

"Indeed customer value is a cornerstone concept of the relationship marketing suggesting that unless value is created and delivered to customers, the firm has no 
legitimate reason to exist nor can accomplish its corporate objectives" (Tzokas and Saren, 2004, p. 127).

In this chapter we adopt Birerty, Eckles, and Reeder's (1998, p. 466) definition of value. For the authors, value is the provision of greater satisfaction at a given price or equal satisfaction at a lower price (p. 466). In addition, the authors emphasize that customers will choose a 'bundle of benefits' that offers the most satisfaction for money. Competitors are getting better; customer needs are ever changing due to, for example, rapid changes in technologies, socio-economic and political changes. Firms that embrace new changes, in the globalized markets, are creating a bundle of benefits ingrained in their products/services, all in the attempt to win and retain customers. A recent development can be seen in the mobile phone industry. Smart phones, as mobile communications devices, are not only embracing just voice, text and games, but also downloading music, video, and television, access to Internet, better camera, GSP, long battery life, and design. The mobile phone industry, which was for the past two decades dominated by Nordic (e.g. Nokia and Ericsson) and Asian firms (e.g. Sony, Toshiba and Panasonic), has now three U.S firms (Apple, Google, and Microsoft) in the forefront of the industry. None of the U.S. firms is said to have its roots in the telecom industry (Di Dimension, September 15, 2011: 22). The performance of the three U.S firms is consistent with Birerty et al's (1988) notion of the provision of 'a bundle of benefits' to customers. The three U.S. firms are providing a bundle of benefits to customers, something which their rivals are not able to match; that gives the three U.S firms some competitive advantages over their competitors.

A firm's ability to create value for customers, as Porter (1985) maintains, will be the source of its growth and profitability and also the source of creating value for shareholders and value for employees (Doyle and Stern, 2006). However, how firms create value for customers in our globalized world should be seen in a wider context. Thus, a firm's ability to create value for customers that will lead to its competitiveness and generate profit, for example, will depend, in large, on how well the firm handles its relationships with some significant actors in the marketplace (Håkansson and Snehota, 1995). For instance, the increased interdependence among firms denotes that goods and services are designed, created, and delivered by sharing knowledge and experiences with others (Anderson and Nerus, 2004). Sandvik's (a multinational company operating in the tooling industry) example of sharing experience and knowledge with some significant actors, while producing value for its customers, is worth reporting here.

"Sandvik contends that the product's performance advantage in the tooling industry is being reduced all the time. To achieve a differential advantages, vis-á-vis its competitors in their competitive market, Sandvik has to stay ahead of competition by, for example, investing so much in research and development and/or working together with universities or research institutes that are in the forefront of technology in metal cutting" (Awuah, 2001, p. 584).

In our globalized world, characterized by, for example, intense competition and fewer barriers to trade, almost all firms, in any industry, share Sandvik's experiences quoted 
above. Whether a services firm (providing mostly intangible solutions) or a manufacturing firm (producing physical or tangible goods) to outperform competitors will mean that the firm must be able to stay ahead of competition by, for example, providing 'a bundle of benefits', which its rivals will not be able to match. Nevertheless, this will demand that the firm invests so much in research and development and/or working together with other actors (e.g. universities or research institutes, customer s, suppliers, and even sometimes with competitors). Submitting to studies elsewhere (Awuah, 2008, 2007; Håkansson and Snehota, 1995; Håkansson, 1987), a firm's efficient use of its internal capacity and its efficient utilization of external capacity will form the firm's 'total capacity'.

In view of the above discussion, there is the need to conceptualize on how a firm can develop its competitiveness in our globalized markets, something that is virtually lacking in the extant literature. As evident in the preceding sections, one important effects of the increased globalization, which the world is witnessing these days, has to do with the extent to which a greater number of firms, from both the developed and from the less developed countries are internationalizing their business activities (Cavusgil, et al., 2012; Carasco and Singh, 2009). A framework to aid our understanding of how a firm will develop its sustainable competitiveness in the competitive global markets would be very useful. Hence, we attempt to conceptualize on factors that affect the development of a firm's competitiveness in our globalized markets.

\section{Theoretical framework}

A firm's ability to operate successfully will depend on how much it is competitive vis-à-vis its rivals. Hammond and Groose (2003) stress that a firm's internationalization of its business activities should be seen as its development of competitive capabilities that enables it to compete successfully against rivals from and within different countries. In Figure 1, a firm is seen to be in a constant search to establish its business relationships in as many as possible markets, foreign and domestic, in order to be able to survive in a globalized world, where competition has become very fierce (Peng et al., 2008; Beamish and Lu, 2004). The intense competition in our globalized world demands that all firms must be well equipped to face the emerged competition by developing their competitiveness vis-á- vis other competitors. That will mean using the firm-specific capabilities to create value for customers in any market (Doyle and Stern, 2006; Porter, 1985). Here, a firm's utilization of its specific capabilities, for example, innovation, learning, and customer- orientation will have to be developed and updated over time. As Doyle and Stern (2006) assert, innovative solutions, no matter where they come from, once they are perceived by customers to be new and superior to some existing alternative solutions, will be preferred by customers. Especially, small - and medium sized enterprises (SMEs) are seen to be very good in internationalizing their businesses by providing innovative solutions to customers (Andersson and Wictor, 2003; Knight and Cavusgil, 1996).

But, as argued above, value creation for customers and other stakeholders, worldwide, should be seen in a wider context, where the firm's performance influences and is 


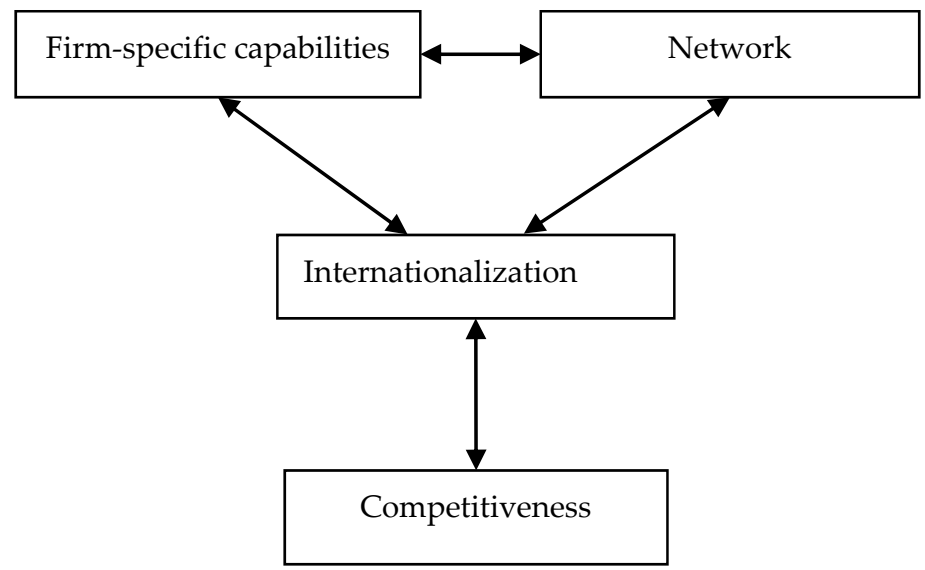

Figure 1. Factors affecting a firm's development of its competitiveness

influenced by other significant actors (Awuah, 2008, 2007; Anderson and Narus, 2004; Håkansson and Snehota, 1995). As Anderson and Narus (2004) assert, a firm designs, produces and delivers goods and services by sharing knowledge and experiences with some significant actors in the marketplace. According to Dunphy et al., (1997), organizations are concerned with learning if it helps them to perform better. However, learning cannot be a sole internal activity. A firm is seen to be embedded in a network of exchange relationships, which enables the firm to have access to complementary resources and activities of other actors in the firm's network (Awuah, 2008; Gummesson, 2002; Håkansson and Snehota, 1995). In interaction with other actors in a firm's network, the firm and the interacting partners engage in mutual learning, which will among other things, enhance the firm's ability to perform better (Tzokas and Saren, 2004; Dunphy et al., 1997). According to Cavusgil, et al, (2012) a firm, which engages in international businesses stands the better chance to learn much about world market than those that are focused only in the domestic market.

For most firms (e.g. those in the global industries such as automobile and telecommunication), the pursuit of growth, the preempting of competitors in their domestic markets, and for survival all suggest that they have to develop and implement internationalization strategies that will enable them achieve the above objectives (Czinkota and Ronkainen, 2007; Pettinger, 2007; Doole and Lowe, 2004) . One crucial strategy for a firm, therefore, would be, according to Pettinger (2007), for a firm to establish physical presence in many foreign markets. For Pettinger (2007), this physical presence is the key to market, economic, social, political and cultural knowledge and understanding.

"Given that consumer and competitive behaviors are deeply rooted in national cultures, SMEs that possess such social knowledge can leverage it in promoting product innovation" (Zahra, S.A., et al., 2009, p. 82)

Most SMEs are seen to be very good in internationalizing their businesses by providing innovative solutions to customers (Andersson and Wictor, 2003; Knight and Cavusgil, 1996). However, whether large or SMEs, the interdependent relationships between most firms 
suggest that a firm and its interacting partners engage in mutual learning, which will among other things, facilitate the development of innovative solutions, enhance a firm's internationalization into unknown markets and becoming customer-oriented (Awuah, 2008, 2007, Tzokas and Saren, 2004; Andersson et al., 2002).

Most studies have underlined a firm's network of exchange relationships as one of the major factors impacting positively on the firm's internationalization. For example, a firm's network of exchange relationships will help the firm determine, which foreign market it will choose to enter and with what entry mode to use (Awuah, et al., 2011; Moen, 2002; Johanson and Vahlne, 2003, 1990). Significantly, a firm's network becomes an important asset, especially when its innovative solutions will have to be brought to several markets, substituting its domestic market with the wider globalized market. All in all, a firm's internal capabilities will be complemented by those of the activities and resources of some of their identifiable network partners, a joint effort that will facilitate a successful internationalization.

A foreign firm may enter any foreign market, thanks to liberalization of many markets, but the ability to develop and sustain its competitiveness, in the face of intense competition and the challenge to handle different parameters (e.g. culture, laws, language, and technologies) will be a tremendous task that must be both understood and managed (Awuah, 2009; Zahra, S.A., et al., 2009; Pettinger, 2007; Hollensen, 2001). As maintained by Blomstermo, et al., (2002, p. 61), a firm's internationalization of its activities has to do, as always, with obtaining knowledge about foreign markets. Lack of knowledge, according to the authors, is still a fundamental problem with most firms' internationalization efforts. The costs and/or knowledge required to undertake some innovative activities, which will strengthen a firm's competitiveness in several markets, can be beyond the capabilities of a single firm. Hence, building and sustaining mutually beneficial exchange relationships with several significant actors in a firm's network will enable the firm to draw on their complementary resources and activities (Svensson and Wood, 2008; Håkansson, et al., 2004; Kotler, 2000). Thus, the firm's development and sustenance of its competitiveness that will enable it to compete successfully against rivals from and within different countries will be a function of its own effective utilization of internal capabilities plus its utilization of external capabilities, to which it has an access as the result of its network of exchange relationships (Awuah, 2008, Johanson and Vahlne, 2003; Håkansson and Snehota, 1995).

Globalization has set into motion forces such as those advanced above to aid our understanding of the extent, to which firms will have to actively participate in the globalized markets so as to be able to create value for customers in any market, an effort which will reflect their competitiveness vis- á-vis their rivals. Consistent with what Hammond and Groose (2003) contend, a firm's internationalization of its business activities should be seen as its development of competitive capabilities or competitiveness that enables it to compete successfully against rivals from and within different countries.

\section{Concluding remark}

In our globalized world, characterized by, for example, intense competition and fewer barriers to trade, almost all firms will have to develop a sustainable competitiveness that 
will enable them to stay ahead of competition in any market where they operate. However, this competitiveness of a firm in our globalized markets will have to translate into the creation of a bundle of benefits, which customers in any market will opt for. This is an effort, which the firm alone cannot develop and maintain, as it competes in our competitive markets. But, as has been discussed above, a firm's embeddedness in a network of exchange relationships impinges on the firm's performance, for example, the creation of value. Since a firm designs, produces and delivers goods and services by sharing knowledge and experiences with others, establishing, developing and maintaining long-lasting exchange relationships with some significant actors in the globalized world will not only facilitate the firm's internationalization, but also strengthen its competitiveness.

To have a sustainable competitiveness, therefore, the firm's internationalization efforts should be strengthened through the firm's effective use of its own internal capabilities and, in addition to that, its efficient utilization of external capabilities, to which it has an access as the result of its network of exchange relationships (Awuah, 2008, Johanson and Vahlne, 2003; Håkansson and Snehota, 1995).

\section{Author details}

Gabriel Awuah

Halmstad University, Halmstad, Sweden

\section{References}

Allen, L., Chakraborty, S, and Watanbe, W. (2011). Foreign direct investment and regulatory remedies for banking crises: Lessons from Japan, Journal of International Business Studies 42, pp. 875-893.

Anderson, J. C., and Narus, J. A. (2004). Business Markets Management: Understanding, creating, and delivering value (2 ${ }^{\text {nd }}$ ed.), Person Education Inc. New Jersey.

Andersson. U., Forsgren, M., and Holm, U. (2002). The strategic impact of external networks: Subsidiary performance and competence development in the multinational corporation, Strategic Management Journal, 23, pp. 979-996

Andersson, S, and Wictor I. (2003), Innovative internationalisation in new firms - born globals: The Swedish case, Journal of International Entrepreneurship, Vol. 1 No. 3, pp. 249-76.

Awuah, G.B. and Amal, M. (2011). Impact of globalization: The ability of less developed countries' (LDCs') firms to cope with opportunities and challenges, European Business Review, Vol. 23 No.1, pp. 120-132.

Awuah, G. (2009). The impact of globalization and trade liberalization on competitiveness of firms in Less Developed Countries: A longitudinal study, International Journal of Business Research, Vol. 9, Number 3, pp. 7-19.

Awuah, G. B. (2008). Analyzing Customer-Orientation Practices of Firms from a Wider Perspective, Journal of Business-to-Business Marketing, Vol. 15 (1), pp. 45-72.

Awuah, G. B. (2007). A professional services firm's competence development, Industrial Marketing Management 36, pp. 1068-1081.

Awuah, G. B. (2001). A firm's competence development through its network of exchange relationships, Journal of Business and Industrial Marketing, 16 (7), pp. 574-599. 
Beamish, P. W., and Lu, J.W. (2004). Network development and firm performance: A field study of internationalizing Japanese firms, The Multinational Business Review, Vol. 12 No. 3, pp. 41-61.

Blomstermo, A., Johanson, J och Pahlberg, C. (2002). "Företags internationaliseringsprocess Lärande i nätverk", Lund, Studentlitteratur.

Brierty, E.G., Eckles, R.W., and Reeder, R.R. (1998). Business Marketing (3 ${ }^{\text {rd }}$ edition), Prentice Hall, New Jersey.

Carasco, E.F, and Singh, J.B. (2009). The evolution of global business ethics conventions, in Indersson, S. and Svensson, G (Eds), Glocal Marketing: Think Globally and Act locally, Studentlitteratur, Lund.

Cavusgil, S. T, Knight, G, and Riesenberger, J.R. (2012). International Business, International Edition, 2 nd ed., Pearson Education Inc., New Jersey.

Curry, J.E. (2000). Internationales Marketing. Neue Märkte erscliessen, (Expasion im Zeichen der Globalisierung), Aus der Englischen Übersetzung. Von Jürgen Ulrich Lorenz, erste Auflage, Köln, Dt. Wirtschaftdienst.

Chuang, M-L., Donegan, J.J., Ganon, M.W., and Wei, K. (2011). Walmart and Carrefour experiences in China: resolving the structural paradox, Cross Cultural Management, Vol. 18 No. 4, pp. 443-463.

Czinkota, M.R, and Ronkainen, I. A. (2007). International Marketing (8 ed), Thomson SouthWestern, United States of America.

Di Dimension, Nr 7, 15 September, 2011: 22-24

Doole, I, and Lowe, R. (2008). International Marketing Strategy: Analysis, Development and Implementation, $5^{\text {th }}$ edition. Cengage Learning EMEA, London.

Doole, I., and Lowe, R. (2004). International marketing strategy - analysis, development and implementation, ( $4^{\text {th }}$ edition), Thomson Learning, London.

Doyle, P. and Stern, P. (2006). Marketing Management and Strategy (4 $4^{\text {th }}$ edition). Pearson Education Ltd. , Edinburgh Gate/Harlow.

Dunphy, D., Turner, D., and Crawford, M. (1997). Organizational learning as the creation of corporate competencies, Journal of Management Development, Vol. 16 No. 4, pp. 232-44.

Financial Times: November 10, 2011:4

Gummesson, E. (2002). Total relationship marketing: Marketing management, relationship strategy and CRM approaches for the network economy, ( $2^{\text {nd }}$ edition). Butterworth Heinemann, Oxford.

Hammond, C., and Groose, R. (2003), 'Rich man, poor man: Resources on Globalization', Reference Service Review, 31: 3, pp, 285-295.

Herald Tribune (June 4-5, 2011:4)

Hollensen, S. (2001). Global marketing: Marketing-response Approach, (2 ${ }^{\text {nd }}$ edition), Prentice-Hall, Essex.

Human Development Report, (2004). Cultural liberty in today's diverse world, paper presented at the United Nations Development Programme, I UN Plaza, New York, NY

Håkansson, H., Harrison, D., and Waluszewski, A. (2004). Rethinking Marketing: Developing a new understanding of markets, Johan Wiley \& Sons Ltd., Chichester.

Håkansson, H.\& Snehota, I. (eds.) (1995). Developing Relationships in Business Networks.

London: Routledge

Håkansson, H. (1987). Industrial technological development: A network approach, Routledge, London. 
Johanson, J., and Vahlne, J-E. (2003). Business relationships, learning, and commitment in internationalization process, Journal of Entrepreneurship, Vol. 1, pp. 83-101.

Johanson, J., and Vahlne, J-E., (190) "The mechanism of internationalization", International Business Review, Vol. 7, No 4, pp. 11-24

Knight, G. and Cavusigil, S. (1996), The born global firm: a challenge to traditional internationalization theory, Advances in International Marketing, Vol. 8, pp. 11-26.

Kotler, P. (2000). Marketing Management, Prentice-Hall, Englewood Cliffs, NJ.

Lee, K. (2005). Global Marketing Management: Changes, challenges, and new strategies, Oxford University Press, Oxford.

Li, S., Qiu, J, and Wan, C. (2011). Corporate globalization and bank lending, Journal of International Business Studies 42, pp. 1016-1042.

Martin, B. (1993). In the Public Interest: Privatization and Public Sector Reform. Zed Books Ltd., London.

Moen. O. (2002). 'The born globals: A new generation of small European exporters, International Marketing Review, Vol. 19, No. 2, pp. 156-175.

Peng, M.W., Wang, D.Y, Jiang, Y. (2008). An institutional-based view of international business strategy: A focus on emerging economies, Journal of International Business Studies 39, pp. 920-936.

Porter, M. (1985). Competitive Advantage: Creating and sustaining superior performance, The Free Press, New York, NY.

Peters, B.G, and Pierre, J. (2006). Handbook of Public Policy, Sage, London.

Pettinger, R. (2007). Introduction to Management, (4th edition), Palgrave Mcmillan, New York, NY.

Spiegel Special: Geschichte - Afrika, das umkämpfte Paradies, Nr. 2/22 - 05-2007.

Stiglitz J. E. (2007). "Fungerande Globalisering", Diadalos AB., Göteborg.

Svensson, G. and Wood, G. (2008). A model of business ethics, Journal of Business Ethics, Vol. 77, pp. 303-22.

Teece, D. (1985). Transaction Cost Economics and the Multinational Enterprise. An assessment, Journal of Economic Behaviours and Organisation 7, pp. 21-45.

Todaro, M. P. (1994). Economic Development, 5 th edition, Longman Publishing, New York.

Tzokas, N., and Saren, M. (2004). Competitive advantage, knowledge and relationship marketing: Where, what and how?, Journal of Business $\mathcal{E}$ Industrial Marketing, Vol. 9 No. 1, pp. 20-42.

Unger, K. (1988). Industrial Structure, technical change and micro-economic behavior in LDCs. In Dosi et al (eds.), (1988). Technical Change and Economic Theory. Pinter Publishers, London.

Wei, L-Q., and Lau, C-M. (2008). The impact of market orientation and strategic HRM on firm performance: The case of Chinese enterprises, Journal of International Business Studies 39, pp. 980-995.

Zahra, S.A., Ucbasaran, D., and Newey, L. R. (2009). Social knowledge and SMEs' innovative gains from internationalization, European Management Review 6, pp. 81-93

www.economywatch.com : Swedish Trade: Accessed 12/10/2010. 